\title{
Survey for the incidence of wilt disease and management of wilt in chickpea
}

\author{
B.K. Lokesh*, N. Shashidhara ${ }^{1}$ and V. Kantharaju ${ }^{2}$ \\ Agriculture Extension Education Centers (U.A.S.) Arabhavi, Gokak, Belgaum (Karnataka) India \\ (Email: lokesharyan1@ rediffmail.com)
}

\begin{abstract}
Chickpea wilt pathogen in association with other soil-borne pathogens like root rots and foot rot also causes extensive damage to chickpea crop. The highest incidence of wilt (12.84 \%) was observed in Neginahala village of Bailhongal taluka. While, the maximum wilt complex incidence of 8.94 per cent was recorded in Inchala village of Savadatti taluk. Followed by 6.18 per cent of wilt incidence was surveyed in Melmatti village of Gokak taluk and 5.64 per cent incidence of wilt complex was observed in Nerali of Hukkeri and 5.64 per cent wilt in Koliguuda of Athani taluk surveyed. higher yield was found in seed treatment with vitavax power, $\mathrm{T}_{4}\left(10.32 \mathrm{qt} / \mathrm{ha}\right.$ ) which was on par with seed treatment with sprint $\mathrm{T}_{5}(9.67 \mathrm{q} / \mathrm{ha}$.). Among all chemicals fungicides and bioagents used for the management of wilt rot complex, the seed treatment with vitavax power (Carboxin+Thiram)@ $2 \mathrm{~g} / \mathrm{kg}$ seed has reduced per cent wilt disease to greater extent with 2.40 PDI and increased yield upto 10.32qt1/ha. Similarly, among various bioagents, seed treatment with Trichoderma harzianum @ 4 g/ kg seed + Soil application of T. harzianum @ $2 \mathrm{~kg}+250$ $\mathrm{kg} \mathrm{FYM}+50 \mathrm{~kg}$ Neem seed powder/ hectare found significant to reduce wilt incidence from 3.65 to 11.11PDI with increased yield 8.67qt//ha to $9.90 \mathrm{qt} / \mathrm{ha}$ during both year and which is on par with seed treatment with T. harzianum @ 5g + P.fluorescens@ 5g/ $\mathrm{kg}$ seed recorded 3.69 to $9.89 \mathrm{PDI}$ with yield ranged 8.92 to $9.50 \mathrm{qt} / \mathrm{ha}$ which indicates when bio control agents were combined exhibit grater control of wilt with higher yield rather than individual bio control agent used.
\end{abstract}

Key Words : Incidence of wilt disease, Management, Wilt in chickpea

View Point Article : Lokesh, B.K., Shashidhara, N. and Kantharaju, V. (2020). Survey for the incidence of wilt disease and management of wilt in chickpea. Internat. J. agric. Sci., 16 (1): 91-94, DOI:10.15740/HAS/IJAS/16.1/91-94. Copyright@ 2020: Hind Agri-Horticultural Society.

Article History : Received : 30.10.2019; Revised : 18.11.2019; Accepted : 21.12.2019

\footnotetext{
* Author for correspondence:

${ }^{1}$ Agricultural Research Station, Arabhavi, Gokak, Belgaum (Karnataka) India

${ }^{2}$ Kittur Rani Channamma College of Horticulture (H.E.U.) Gokak, Belgaum (Karnataka) India
} 